\title{
Prospects of using new non-standard employment forms at Russian enterprises
}

\author{
Inga Tsygankova ${ }^{1 *}$, Natalia Ivanova $^{2}$ \\ ${ }^{1}$ St. Petersburg State Economics University, 191023, Saint-Petersburg, Russia \\ ${ }^{2}$ Peter the Great St. Petersburg Polytechnic University, 195251, Saint-Petersburg, Russia
}

\begin{abstract}
The article presents the theoretical analysis of non-standard employment new forms, the reasons of their origin, the advantages and disadvantages for the employee. The authors identified the most promising forms of non-standard employment, which give advantages to wage workers and improve their position in the labor sphere. Based on the results of the study of new non-standard employment forms at Russian enterprises the dependence between a particular form employment and the kind of economic activity, in which the enterprise operates, as well as the category (or qualification group) of employees has been identified. The spheres, in which there is a potential for the development of non-standard employment new forms, are shown.
\end{abstract}

\section{Introduction}

Non-standard employment has become a constant phenomenon, both on the Russian labor market and on the labor markets of foreign countries. The scale of its spread increases every year. In recent decades, new forms and models of non-standard employment have appeared, which there were not before (outsourcing, freelancing, tele-labor, etc.).

A number of publications by domestic and foreign authors are devoted to the problems of non-standard employment, but it remains an unexplored phenomenon, requiring further research and development, because, on the one hand, various forms of employment have been studied only fragmentarily. On the other hand, they significantly influence on the socio-economic position of the worker in the labor sphere, improving it or worsening. It ultimately affects the development of the country whole economic system.

In the domestic literature there is no single interpretation of the term "non-standard employment". More often non-standard employment includes all kinds of employment, which differ from the classical model of capitalist wage labor [1, p. 29].

Many foreign researchers (S. Flüter-Hoffman, J. Solbrig, K. Linnenkohl, R. Winniger) connect with standard employment such kind of employment as the full-time employment on the basis of an indefinite or long-term employment contract under leadership of a manager or employer [2, p. 6; 3, p. 13, 4, p. 9]. Thus, nonstandard forms by "default" include all the others, that are not related to this definition.

A number of Russian researchers, considering various forms of employment, do not use the term "nonstandard employment" [5, p. 77]. Many foreign authors also do not use this term (A. Büssing, A. Drodofsky, N. Warkentin, U. Hellert, H. Klein-Schneider) [6-9].

Some authors use the term "forms of labor relations", rather than "forms of employment", examining so-called sourcing forms (outsourcing, insourcing, crowdsourcing) [10]. But we believe that not all these forms of the relationship between the employee and the employer can be considered as forms of employment or forms of labor relations. According to the Labor Code of the Russian Federation, labor relations are relations, based on an agreement between an employee and an employer on personal performance of an employee's labor function for a fee [11]. So, crowdsourcing is the involvement of a people wide range for using their creative abilities, knowledge and experience to solve any tasks or problems of the enterprise with help of telecommunication and Internet technologies. Often it does not include working at the enterprise and receiving labor reward. In our opinion, crowdsourcing is more a technology to attract new ideas in the organization and search of their implementation opportunities, rather than the form of employment.

Classifications of non-standard employment forms, presented in domestic and foreign sources, are very diverse. For example, according to different authors, non-standard employment includes as temporary, seasonal, home-based employment, employment on calls, part-time, so and informal employment, incomplete, overtime, casual, secondary employment [12], distance employment, borrowed labor [13].

Practically in all publications of German authors forms of non-standard employment are considered from the view of their flexibility in the labor market $(\mathrm{N}$. Warkentin, C. Flüter-Hoffman, J. Solbrig, A. Hoff, C. Hahn, J. Gutman, J. Hüsgen) [8, 2, 14, 15, 16]. A. Hoff

Corresponding author: icygankova@list.ru 
identifies such forms of flexible employment as work on standard schedules with flexible start and end of the working day, the flexible sliding working time, working time on trust with presentation of the final result $[15, \mathrm{pp}$. 5-13]. Р. Наnau и А. Veit considers work time accounts as a form of employment and their various models [17]. F. Lorenz и G. Schneider allocates among flexible forms of employment working time on trust, work time accounts and flexible models of part-time work and shift work [18]. The publications of N. Kordey present the advantages and disadvantages of the tele-labor and its various models [19].

\section{Formulation of the problem}

Among all the variety of the non-standard employment forms, it is possible to highlight out "new", emerging at the beginning of the 21 st century, during the period of the formation of the postindustrial economy, and "old", "traditional" forms, which were spread even before the 1990s., both in countries with a market economy, and in the planned socialist economy, that existed in the USSR, or in the economy of the Russia transition period in the 1990s. [20, pp. 72-73]. As a basis, the authors took such classification indicator, as a period of emergence, since the employment forms which are characteristic for the information age were formed precisely in the last decades.

To traditional forms of non-standard employment it is possible to carry: incomplete employment, temporary, non-permanent or accidental employment, selfemployment, home-based labor, work on sliding schedules, shift work. The introduction of non-standard employment "old" forms was due, for the most part, to the specifics of the enterprises work (orientation to the internal environment), while the emergence of new forms was caused by the influence of external environment factors.

Thus, the emergence of the majority of "new" forms and models of non-standard employment became possible due to the development of information technologies.

New forms of non-standard employment should be considered in more detail, since they have prospects for development on the Russian labor market in subsequent years. According to the authors, it is necessary to investigate the advantages and disadvantages of nonstandard employment forms, since this aspect of the problem influences on the position of the worker in the labor sphere, the economic system as a whole, largely determines the state of the domestic labor market and the prospects of the separate forms development and models of employment in future.

The object of work are selected Russian enterprises, using forms of non-standard employment (practical significance).

The scientific novelty of the research is contained in the author's approach to the classification of nonstandard employment new forms, adapted to Russian enterprises conditions, identifying the reasons of their appearance, assessing the impact on the position of the employee and revealing the most promising forms.

\section{Specificity of non-standard employment new forms at the enterprise}

The main reasons of the non-standard employment new forms emergence, in our opinion, are:

- the aspiration of the employer to reduce labor costs;

- the need to change the organization of labor in order to meet the needs of consumers (the organization of enterprises work or separate departments on weekends and holidays, at night, etc.), that was accompanied by the flexibility of using working time;

- the aspiration of the employee to improve his position in the sphere of labor and employment (increase the chances of finding a job, improve the ratio of free and working time, choose the most suitable days and hours of work).

The non-standard employment new forms can be divided into four groups:

- sourcing forms (outsourcing, outstaffing, staff leasing, insourcing);

- various forms of distance employment (tele-labor, work at a virtual enterprise);

- flexible forms of work (working hours with flexible start and end of the working day, the flexible sliding working time, accounts of working time, etc.);

- freelancing.

Since we evaluate the impact of employment separate forms on the position of the employee at the enterprise, the form of non-standard employment like freelancing, will not be considered, because freelancers are in most cases self-employed. Let us analyze in more detail the first three groups of non-standard employment new forms (table 1).

Sourcing forms were developed in Russia in the second decade of the 21 st century. The most common form in this group was outsourcing - transfer by an organization of secondary functions on importance or of non-core functions to another organization for a sufficiently long period (a year and more). Until 2016 on the domestic labor market outsourcing, along with such forms as outstaffing and staff leasing, developed within the framework of borrowed labor [21, 22]. But from January 1, 2016, Russia accepted a law, which significantly limited the use of borrowed labor [23], in order to protect staff, working in these forms. In this regard, the scales of the employment above-mentioned forms using has significantly decreased, but remained on the Russian labor market.

In recent years Russian enterprises have been developing insourcing - the transfer of a "non-profile" project, which is usually performed by a third-party organization, employee or department within the enterprise. Insourcing has appeared on the Russian labor market quite recently and is not connected with borrowed labor. As a form of employment, it differs from part-time employment in that employees, who implement insourcing projects, do not work on them on 
an constant basis, but from time to time when it becomes necessary. In this case they work permanently in a completely another position.

The appearance of absolutely all sourcing forms was caused by the aspiration of the employer to cut costs. Therefore, these forms give more advantages to the employer than to the employee. Otherwise, he simply avoids of using them.

Adoption of a law, restricting the use of borrowed labor, contributed to improving the position of borrowed workers, at the same time their position on the labor market is worse than ordinary, "standard" workers.

In the last decade distance employment has spread on the world labor market due to the need of the labor organization changing from the side of the employer and in connection with the aspiration of the employee to improve his position in the sphere of labor. Tele-labor is a labor activity, which is organized remotely from the employer and can exist thanks to the development of information and telecommunication systems [24]. Telelabor can be exclusively remote, or alternative - when an employee comes to the enterprise at least once a week [25, pp. 57-59]. The second model is more spread and gives more advantages (see table 1 ).

This form of distance employment, like work at a virtual enterprise, appeared on the Russian labor market quite recently. A virtual enterprise is usually understood as an enterprise, consisting of a community of geographically separated economic entities, which cooperate in the production process, using primarily electronic means of communication. In this case, there is generally no main, "parent" enterprise, and employees work at home. They are mobile, use the satellite bureau and communicate among themselves through telecommunications. Virtual enterprises exist in different kinds of economic activity, but in European countries and the United States their number is the highest in information technology and industry.

On the world market examples can serve as Mentor Graphics (design of electronics and electrical engineering, development of software products for industrial design); Katana Software (development of software products); Core Geomatics (geological exploration in the oil and gas and construction sectors); Elbes (viewing and selection of the most successful and interesting projects in the field of culture and their further promotion). In Russia examples of virtual enterprises are NOU "Intuit" - distance learning in the field of information technology, a virtual pharmacies network "Pilulu.ru". At the moment the number of virtual enterprises is small. But on the Russian labor market there are companies, that provide consulting services for virtualizing the customer's business (for example, LLC "Web segment").

Table 1. The non-standard employment new forms at the enterprise and their characteristic *.

\begin{tabular}{|c|c|c|c|}
\hline $\begin{array}{c}\text { Forms of } \\
\text { employment }\end{array}$ & Reasons of appearance & Advantages for an employee & Disadvantages for an employee \\
\hline $\begin{array}{l}\text { 1. Sourcing forms } \\
\text { (outsourcing, } \\
\text { outstaffing, staff } \\
\text { leasing, } \\
\text { insourcing) }\end{array}$ & $\begin{array}{l}\text { The aspiration of the employer } \\
\text { to reduce labor costs }\end{array}$ & $\begin{array}{l}\text { Opportunity to save / receive a } \\
\text { working place and / or a certain } \\
\text { income. } \\
\text { Enrichment of labor and gaining } \\
\text { experience of work in an adjacent } \\
\text { or even completely different } \\
\text { sphere (for insourcing) }\end{array}$ & $\begin{array}{l}\text { Decrease of the employment } \\
\text { stability and income from labor } \\
\text { activity. } \\
\text { Limited opportunities for career } \\
\text { growth. } \\
\text { Decrease of labor productivity } \\
\text { and satisfaction with labor. } \\
\text { The emergence of labor conflicts }\end{array}$ \\
\hline $\begin{array}{l}2 . \quad \text { Forms of } \\
\text { distance } \\
\text { employment (tele- } \\
\text { labor, work at a } \\
\text { virtual enterprise) }\end{array}$ & $\begin{array}{l}\text { The aspiration of the employer to } \\
\text { change the organization of labor in } \\
\text { order to meet the needs of the } \\
\text { consumer. } \\
\text { The aspiration of the employer to } \\
\text { cut costs of: } \\
\text { - the creation and content of certain } \\
\text { working places at the enterprise; } \\
\text { - the payment of workers in their } \\
\text { region in the event that he can use } \\
\text { cheaper, but no less qualitative } \\
\text { labor of workers from other regions } \\
\text { / countries }\end{array}$ & $\begin{array}{l}\text { The opportunity to allocate } \\
\text { working time at own discretion. } \\
\text { Minimum control by the } \\
\text { employer. } \\
\text { The opportunity of a combination } \\
\text { of professional life and training, } \\
\text { education of children and } \\
\text { training. } \\
\text { Increasing the duration of free } \\
\text { time in the case of effective work. } \\
\text { Getting the opportunity of } \\
\text { employment for people with } \\
\text { limited opportunities and workers } \\
\text { from remote or depressed regions }\end{array}$ & $\begin{array}{l}\text { Risk of a decline in the work } \\
\text { quality. } \\
\text { Risk of partial loss of } \\
\text { competence. } \\
\text { Decrease of opportunities for } \\
\text { career growth and position } \\
\text { promotion. } \\
\text { The danger of social isolation. } \\
\text { The risk of a decline of labor } \\
\text { productivity and an increase in } \\
\text { the duration of working time in } \\
\text { the working place at home }\end{array}$ \\
\hline $\begin{array}{l}\text { 3. Flexible forms } \\
\text { of work (working } \\
\text { time with flexible } \\
\text { start and end of } \\
\text { the working day, } \\
\text { the flexible } \\
\text { sliding working } \\
\text { time, accounts of } \\
\text { working time, } \\
\text { etc.) }\end{array}$ & $\begin{array}{l}\text { The aspiration of the employee to } \\
\text { improve his position in the sphere } \\
\text { of labor and employment. } \\
\text { The aspiration of the employer to } \\
\text { change the organization of labor in } \\
\text { order to satisfy the needs of the } \\
\text { consumer }\end{array}$ & $\begin{array}{l}\text { The opportunity of own working } \\
\text { time planning. } \\
\text { Higher motivation for labor and } \\
\text { satisfaction with labor. } \\
\text { The opportunity to combine work } \\
\text { and learning }\end{array}$ & $\begin{array}{l}\text { The ban on pay increasing as a } \\
\text { result of increase in working time } \\
\text { (when the working time accounts } \\
\text { using) }\end{array}$ \\
\hline
\end{tabular}

* The table was developed by the authors 
Flexible forms of work are characterized by flexibility in the use of working time, and therefore give a number of advantages to both the employee and the employer [26, pp. 67-70; 27]. The most widespread is a work on a flexible schedule with a free start and end of the working day, flexible sliding working time, working time accounts. In Russia work on a flexible schedule with a free start and end of the working day and work on sliding schedules with a free start and the end of the working day are more often used in trade and services than in industry. These forms of work have found application in the network of supermarkets "Lenta" (trading), in LLC "SPA Interro" (software development, rendering services in the field of computer technologies) [20].

The working time accounts - a non-standard employment form, contributing to the rational use of working time [28, pp. 14-18]. This form can be introduced at the enterprise for all staff, or for a separate category of employees. For the employee a so-called "personal account" is created, to which the difference between normative and actual working time is credited. The working time accounts contain information on temporary accruals and arrears in time, which must be compensated till a certain term, or within a certain time period (for example, a month). If the actual worked time will be more than the normative time worker should have a rest period. In European countries the accounts are widely distributed (used at the enterprises of JSC "German Post", "Glass Workshops of Lower Saxony", "Brewery of North Rhine-Westphalia", JSC "Volkswagen", etc.). Russian legislation limits the possibilities of their application.

\section{The results of the non-standard employment new forms application at Russian enterprises}

The research of the non-standard employment certain forms application at the Russian enterprises was conducted in 2013 and 2016. Such an analysis does not allow us to assess the degree of the various forms spread in the country as a whole. But it gives a representation of the development trends of individual forms in enterprises of various kinds of economic activity, and also allows us to understand, for which groups of workers they are predominantly used.

The information, obtained in the course of the enterprise survey (see table 2), show, that non-standard employment was applied at all considered enterprises. But at the same time, the proportion of people, using of non-standard employment forms, was small and amounted in 2013 to no more than $20 \%$ of the total number of staff. An exception was the enterprise of the LLC "SPA Interro", where almost half of the employees worked with the use of non-standard employment. The enterprises used mainly traditional forms of employment: incomplete, temporary employment and shift work.
New forms of non-standard employment, which give advantages to employees, were used only by LLC "SPC Kriochrome" and LLC "SPA Interro". It can be concluded that the most widely spread new forms of work in the field of information technology (the range of forms used in the LLC "SPA Interro" is the most extensive), while in construction - on the contrary, the traditional forms are used.

Distance employment and work flexible forms are used mainly for specialists, while temporary employment and outsourcing are - for low-skilled workers. The choice of standard or non-standard employment is not due to the wishes of employees, but in most cases - to the specifics of the enterprise's activities (equipment operation modes and production technology). At two of the four surveyed enterprises the employee, where using non-standard employment, can plan the beginning and end of the working day himself, that is, it has advantages in the distribution of his working time.

According to the enterprises survey results in 2016, the following ones can be selected.

At the enterprises of LLC "SPC Kriochrome" and LLC "SPA Interro", which were included in the sample in 2013, the forms of employment, used for employees, have not changed, but the share of employees, for whom they are used, has increased (by $15 \%$ at LLC "SPC Kriochrome", by $10 \%$ in LLC "SPA Interro"). The opinion is confirmed, that borrowed labor and temporary employment are mainly used for low-skilled workers (LLC "Alternative"). As in 2013, the choice of standard or non-standard employment is mainly due to the specifics of the enterprise's activities. At some enterprises due to the specifics of the activity the use of work flexible forms is not possible (FSUE "State Corporation for ATM").

\section{Conclusion}

Based on the results of the theoretical and practical research of the non-standard employment new forms application at Russian enterprises, the following conclusions can be made.

1. Now the size of the spread of non-standard employment new forms at Russian enterprises is low, but the number of workers, using them, is gradually increasing.

2. It is advisable to use new forms of employment at industrial enterprises, since they determine the effectiveness of the economic system functioning, are the sphere, where innovations are applied and scientific and technological progress is taking place.

3. The aspiration of employers to reduce labor costs has led to the emergence or increase of the employment forms prevalence, that negatively influence on the position of employees at the enterprise.

4. The change of the regulatory and legislative framework in the sphere of the borrowed labor application in Russia has improved the position of employees. However their position is worse than that of 
ordinary workers at the enterprise, and the level of wage is significantly lower. Despite the fact that the scales of the borrowed labor application has declined, it remains enough a spread phenomenon for Russian enterprises.

Table 2. The use of non-standard employment at some Russian enterprises in 2013-2016 *.

\begin{tabular}{|c|c|c|c|c|c|c|}
\hline Business name & $\begin{array}{l}\text { Kind of } \\
\text { economic } \\
\text { activity }\end{array}$ & $\begin{array}{l}\text { Forms of non- } \\
\text { standard } \\
\text { employment, used in } \\
\text { the enterprise }\end{array}$ & $\begin{array}{l}\text { The proportion } \\
\text { of employees, } \\
\text { working in the } \\
\text { framework of } \\
\text { non-standard } \\
\text { employment } \\
\text { forms (from the } \\
\text { total number of } \\
\text { personnel), } \%\end{array}$ & $\begin{array}{l}\text { Categories or } \\
\text { groups of } \\
\text { employees, } \\
\text { for whom } \\
\text { non-standard } \\
\text { employment } \\
\text { forms are } \\
\text { used }\end{array}$ & $\begin{array}{l}\text { The } \\
\text { employee } \\
\text { has the } \\
\text { right to } \\
\text { choose the } \\
\text { form of } \\
\text { employment } \\
\text { (yes / no) }\end{array}$ & $\begin{array}{l}\text { The } \\
\text { employee } \\
\text { has the } \\
\text { opportunity } \\
\text { to allocate } \\
\text { working } \\
\text { time at his } \\
\text { discretion } \\
\text { (yes / no) }\end{array}$ \\
\hline $\begin{array}{c}\text { LLC "SPC } \\
\text { Kriochrome", }\end{array}$ & $\begin{array}{c}\text { Chemical } \\
\text { industry } \\
\text { (production of } \\
\text { chemically } \\
\text { pure solvents) }\end{array}$ & $\begin{array}{c}\text { Incomplete } \\
\text { employment (for } \\
\text { students-trainees), } \\
\text { distance employment } \\
\text { (tele-labor) }\end{array}$ & $\begin{array}{c}1-5 \\
(2013) \\
10-20 \\
(2016)\end{array}$ & $\begin{array}{c}\text { Specialists of } \\
\text { the } \\
\text { engineering } \\
\text { and technical } \\
\text { profile, } \\
\text { students- } \\
\text { trainees }\end{array}$ & No & Yes \\
\hline $\begin{array}{c}\text { LLC } \\
\text { "Vozrozhdenie" }\end{array}$ & $\begin{array}{l}\text { Construction, } \\
\text { production of } \\
\text { building } \\
\text { materials }\end{array}$ & $\begin{array}{c}\text { Temporary } \\
\text { employment (for } \\
\text { workers), outsourcing } \\
\text { (for workers) }\end{array}$ & $\begin{array}{c}10-20 \\
(2013)\end{array}$ & Workers & No & No \\
\hline $\begin{array}{c}\text { CJSC } \\
\text { "Kokkomyaki } \\
\text { Quarry" }\end{array}$ & $\begin{array}{l}\text { Extraction and } \\
\text { processing of } \\
\text { natural } \\
\text { resources }\end{array}$ & $\begin{array}{c}\text { Temporary } \\
\text { employment (for } \\
\text { workers), shift work }\end{array}$ & $\begin{array}{c}6-10 \\
(2013)\end{array}$ & Workers & No & No \\
\hline $\begin{array}{l}\text { LLC "SPA } \\
\text { Interro" }\end{array}$ & $\begin{array}{c}\text { Software } \\
\text { development, } \\
\text { services } \\
\text { provision in the } \\
\text { field of } \\
\text { computer } \\
\text { technology }\end{array}$ & $\begin{array}{c}\text { Distance employment, } \\
\text { work with flexible } \\
\text { start and end of the } \\
\text { working day, flexible } \\
\text { part-time } \\
\text { employment, flexible } \\
\text { shift work }\end{array}$ & $\begin{array}{l}31-50 \\
(2013) \\
41-60 \\
(2016)\end{array}$ & $\begin{array}{l}\text { Specialists on } \\
\text { the cable } \\
\text { networks } \\
\text { installation, } \\
\text { specialists on } \\
\text { video } \\
\text { surveillance } \\
\text { systems, } \\
\text { WEB- } \\
\text { developers }\end{array}$ & $\begin{array}{l}\text { Yes, in some } \\
\text { cases } \\
\text { (depending } \\
\text { on position) }\end{array}$ & Yes \\
\hline $\begin{array}{c}\text { LLC } \\
\text { "Alternative" }\end{array}$ & $\begin{array}{c}\text { Laying of } \\
\text { networks and } \\
\text { pipes }\end{array}$ & $\begin{array}{l}\text { Borrowed labor } \\
\text { (outstaffing, } \\
\text { outsourcing) (for } \\
\text { workers of low } \\
\text { qualification, for non- } \\
\text { core specialists), } \\
\text { temporary, inconstant } \\
\text { employment }\end{array}$ & $\begin{array}{c}6-10 \\
(2016)\end{array}$ & $\begin{array}{l}\text { Workers at } \\
\text { the facility, } \\
\text { much less } \\
\text { often - non- } \\
\text { profile } \\
\text { specialists }\end{array}$ & No & No \\
\hline $\begin{array}{c}\text { FSUE "State } \\
\text { Corporation for } \\
\text { ATM" }\end{array}$ & $\begin{array}{c}\text { Aircraft } \\
\text { Management }\end{array}$ & $\begin{array}{l}\text { Shift work without } \\
\text { flexible schedule }\end{array}$ & $\begin{array}{l}11-30 \\
(2016)\end{array}$ & $\begin{array}{c}\text { Specialists, } \\
\text { workers }\end{array}$ & No & No \\
\hline
\end{tabular}

* The table was developed by the authors

5. The greatest chances for success have those enterprises, in which the interests and benefits of employees and employers are balanced. Such forms of employment as distance work (tele-labor and employment at a virtual enterprise), flexible forms of work contribute to the employees position improvement in the labor sphere.

6. Distance employment has a good development potential in the coming years, as it gives a number of advantages to both and employers.

7. The opportunities of the employment certain forms application are determined by the kind of economic activity and the enterprise work specifics. The enterprises, operating in the field of information technologies, are the most susceptible to new forms of employment. Flexible forms of work and distance employment are used primarily for specialists and other highly skilled employees, borrowed labor is used mainly for workers, engaged in low-skilled labor.

\section{References}

1. I.D. Kotlyarov, Issues of economics regulation, $\mathbf{4 , 6}$, 29 (2015)

2. C. Flüter-Hoffman, J. Solbrig, Arbeitszeitflexibilisierung: Erfolgskonzept auch für kleine und mittlere Unternehmen (Köln, 2003) 
3. K. Linnenkohl, Arbeitszeitflexibilisierung. Die Unternehmen und ihre Modelle (Heidelberg, 2014)

4. R. Winiger, Praxishandbuch flexible Arbeitszeitmodelle: Methoden, Konzepte und Vorgehensweisen für die Einführung und Optimierung flexibler Arbeitszeitmodelle (Zurich, Praxium-Verlag, 2014)

5. I.M. Aliev, N.A. Gorelov, L.O. Ilyina, The Economy of Labor (Moscow, Publishing House Yurayt, 2016)

6. U. Hellert, Arbeitszeitmodelle der Zukunft (HaufeLexware, Freiburg, 2008)

7. A. Büssing, A. Drodofsky, K. Hegendörfer, Telearbeit und Qualität des Arbeitslebens (HogrefeVerlag, Göttingen, Bern, Toronto, Seattle, 2003)

8. N. Warkenting, Flexible Arbeitszeiten: Eine Übersicht der verschiedenen Modelle. http://karrierebibel. de/flexible-arbeitszeitenuebersicht-der-modelle/.

9. H. Klein-Schneider, Flexilbe Arbeitszeit Vertrauensarbeitszeit (Memmingen, Bund-Verlag, 2011)

10. R.A. Dolzhenko, Kadrovik, 6, 54-64 (2016)

11. The Labor Code of the Russian Federation no. 197FL of 2001. www.consultant.ru.

12. V.E. Gimpelson, R.I. Kapelyushnikov, Nonstandard employment in the Russian economy (Economics State Higher School Izd. House, Moscow, 2006)

13. R.P. Kolosova, T.O. Razumova, M.V. Ludanik, The population employment forms in the innovative economy (Max Press, Moscow, 2008)

14. C. Hahn, Flexible Arbeitszeit (C.H. BeckVerlag, 2014)

15. A. Hoff, Gestaltung betriebliche Arbeitszeitsysteme (Wiesbaden, Springer Fachmedien, 2015)

16. J. Gutman, J. Hüsge, Flexible Arbeitszeit: Wie Sie moderne Konzepte und Modelle nutzen (Bersgel, Haufe, 2005)
17. P. Hanau, A. Veit, A. Hoff, Recht und Praxis der Arbeitszeitkonten: Wertguthaben, Altersteilzeit, Flexikonten (Aktuelles Recht für die Praxis) (C.H. BeckVerlag, 2015)

18. F. Lorenz, G. Schneider, Vertrauensarbeitszeit, Arbeitszeitkonten, Flexi-Modelle: Konzepte und betreibliche Praxis (VSA, 2004)

19. N. Kordey, Telearbeit erfolgreich realisieren: Das Umfassende, Aktuelle Handbuch Für Entscheidungsträger Und Projektverantwortliche (Braunschweig - Wiesbaden, 2013)

20. I.V. Tsygankova, V.A. Bazzhina, O.Y. Nikishina, Russian Entrepreneurship, 24(270), 71-85 (2014)

21. A.V. Kumakova, N.G. Ivanova, SPbGPU Science Week: materials of the scientific and practical conference with international participation. SPbGPU Humanitarian Education Institute, 233236 (2014)

22. A.V. Kumakova, N.G. Ivanova, SPbGPU Science Week: materials of the scientific and practical conference with international participation. SPbGPU Humanitarian Education Institute, 231233 (2014)

23. Federal Law 116-FL of 2014 "On Amending Certain Legislative Acts of the Russian Federation". www.consultant.ru.

24. M. Sieber, P. Recknagel, Ich bin dann mal im Home Office (Leobell, 2014)

25. I.V. Tsygankova, Saratov State Social and Economic University Bulletin, 1(20), $57-59$ (2008)

26. I.V. Tsygankova, Man and labour, 2, 67-70 (2008)

27. M. Zölich, M. Oertig, V. Calabro, Flexible Workforce - Fit für die Herausforderungen der modernen Arbeitswelt? Strategien, Modelle, Best Practice (Bern, Hauht, 2016)

28. I.V. Tsygankova, Novosibirsk State University Bulletin, 4, 14-18 (2008) 